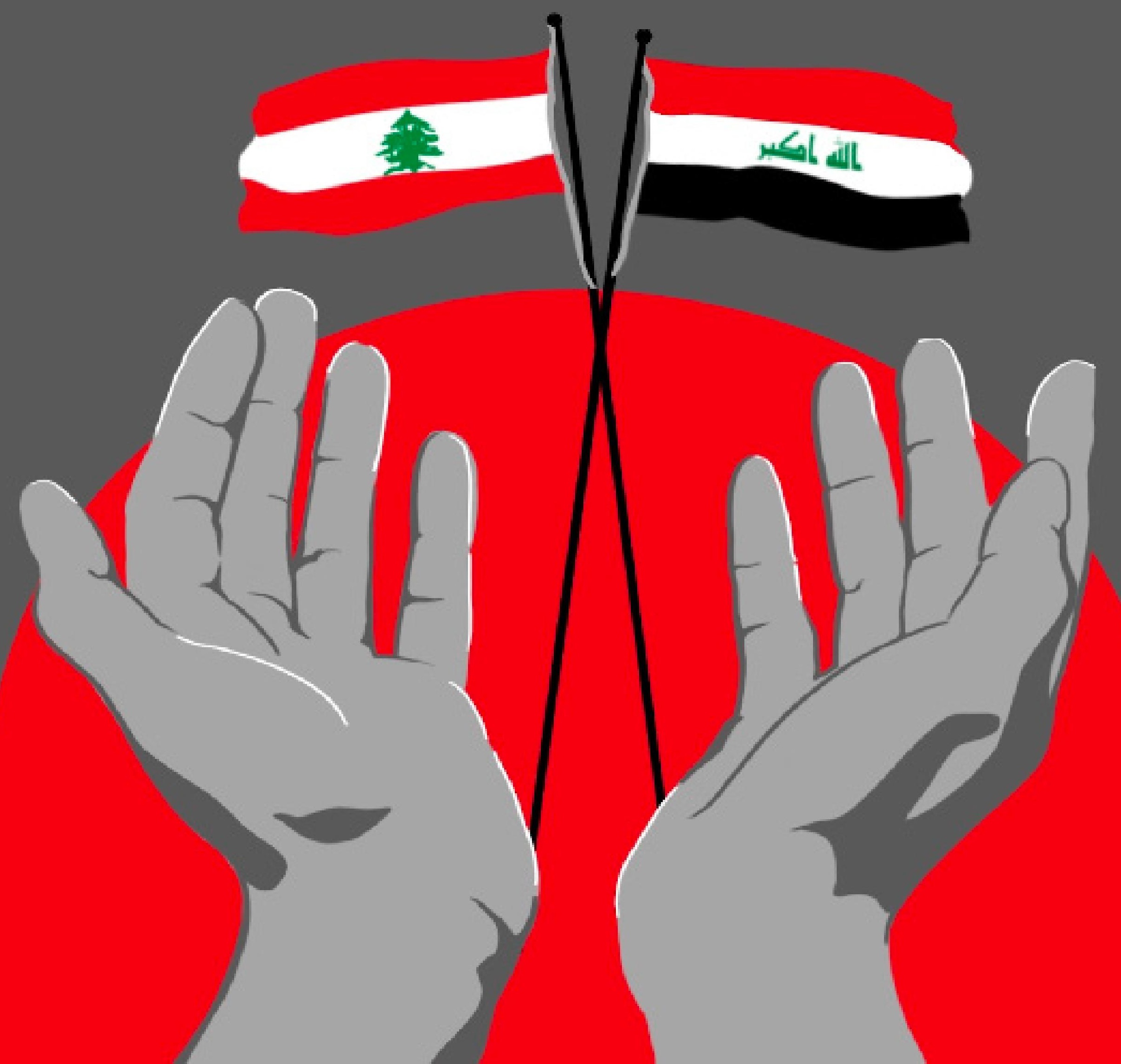

\title{
Lebanon and Iraq: Two Distinct Demonstrations of Confessionalism's Failure to Manage Ethnic and Religious Pluralism
}

Nour Mohsen

Edited by Madelyn Evans and Sophia Perring

ABSTRACT - The Iraqi and Lebanese political systems stemmed from each country's distinctive mosaic of sub-national identities but have been deemed corrupt and incompetent, prompting ongoing protests and calls for unity in both contexts. However, this dissatisfaction is unsurprising given the challenging task of translating the ethnic, linguistic, and religious diversity that characterizes each population into an overarching national identity. The Lebanese and Iraqi political systems have attempted to manage ethnic and religious pluralism through Confessionalism, or a "consociational government which distributes political and institutional power proportionally among religious sub-communities." This paper argues that Lebanon and Iraq are two specific examples of confessionalism, demonstrating its failure to manage ethnic and religious pluralism, which seems to inevitably beget sectarianism - a discriminatory structure in which each group advances its privileges at the expense of others. Nevertheless, Confessional systems are challenging to transform, namelybecause theyinstitutionalize differentethnic or religious groups'identities instead of promoting a unified, national identity. 
T raqis flooding the streets of Baghdad in October 2019 cried "We want a homeland". Almost like an echo, Lebanese protesters on the other side of the Arabian Peninsula were chanting "one, one, one, we are one people" (Zahra and Ali 2019). Just over a year later, despite a decreased momentum due to the COVID-19 pandemic, Lebanese and Iraqis alike are still calling for unity in the protests against their respective political systems, deemed corrupt and incompetent, in what is now often referred to as the second Arab Spring (Muasher 2019). This urge for unity across the whole population is particularly interesting in the cases of Lebanon and Iraq, given that the political systems they are now objecting to stem from their distinctive mosaics of sub-national identities.

Indeed, Lebanon, with its eighteen recognized religious sects, and Iraq, with the significant presence of three different groups - the Sunni Arabs, the Sunni Arabs, the Shi'ite Arabs and the Kurdsas well as a multitude of other minorities, are both notable examples of the Middle East's religious and ethnic diversity. In order to maintain stability in a country with a presence of such varied groups, a pluralist system is required. Pluralism permits diverse communities with "overlapping but distinctive ethics and interests" to all engage politically with a common system of government, while allowing each one to maintain and develop its own traditions (Banchoff 2008).

Pluralism and building a bridging national dentity can be very difficult to achieve, especially when the language, religion, and ethnicity of the groups diverge, as is the case with the Iraqi Sunni Kurds and Iraqi Arab Shiites or Lebanese Sunnis and Lebanese Greek Catholics. Different countries have chosen different models to manage pluralism. Some countries, especially EuroAmerican states, opt for secular democracies which give everyone the same political voice, no matter their sub-affiliation, and instead implicitly hint at the respect for diversity through some form of assimilation such as multiple national languages (Murray 2018). On the other hand, political scientist Arend Lijphart argues that the most appropriate form of government for very segmented populations, like Lebanon and Iraq is a 'consociational democracy'(3). In such systems, the power is distributed between the elites of each different segment of the population. The goal is to instill stability by promoting the attainment of a consensus through consultation and dialogue between the elites (Murray 2018). The current Lebanese and Iraqi political systems attempt to manage their ethic and religious pluralisms through this second option. More precisely, they are, formally in the case of Lebanon and informally in the case of Iraq, confessionalist systems. Confessionalism is the specific type of "consociational government which distributes political and institutional power proportionally among religious sub-communities" (Canadians for Justice and Peace in the Middle East (CJPE) 2007).

The ongoing protests calling for the dismantlement of these political systems lead us to question how effectively confessionalism manages ethnic and religious pluralism. Essentially, regardless of the fundamental differences in their ethnic and religious compositions, their political histories, and the underlying processes of their political systems, both Iraq and Lebanon demonstrate that confessionalism is currently not a successful means of managing ethnic and religious pluralism. In fact, this system has led to widespread dissatisfaction in both countries, with nation-wide protests requesting for a complete overhaul of the political elite. Ultimately, these systems have failed as they seem to inevitably lead to sectarianism - a discriminatory structure in which each group, and particularly its elite, seeks their own privileges at the expense of others. Confessionalism is all the more inefficient and problematic as in spite of public dissatisfaction, these are systems which are extremely difficult to transform; this difficulty arises out of an overpowering of ethnic/ religious group identity over national identity.

To make this argument, this paper will begin by demonstrating how the diversity in Iraq and in Lebanon has led to a similar outcome despite their differences: the creation of confessionalistbased systems. Then, it will reveal that the instability causing the current protests in both countries is either directly or indirectly caused by sectarianism, which appears to be an inevitable consequence of the confessional system. Finally, it will suggest that despite the evident inability of this system to manage ethnic and religious pluralism, no major changes should be expected in the foreseeable future as this system is a positive feedback loop; even though people theoretically want to e sectarian party lines, thei strongest identity ties seem to remain with
their sub-community rather than to their nation.

From Ethnic and Religious Diversity to Confessionalism

Ethnic and Religious Compositions

Despite different ethnic and religious compositions of their population, different historical backgrounds, and different formal constitutional texts, both Iraq and Lebanon have come to implement pluralism today through a form of confessionalism. To understand these countries' political systems and their management of pluralism, it is first essential to understand how diverse they both are and how the different groups are organized. Although resembling each other in their ethnic and religious diversity, Lebanon and Iraq differ in the proportion of the different groups, their types, and their geographical distribution. While the community division of the Lebanese population recognized by the state is strictly by religious affiliation, the division in Iraq is a more complex ethno-religious one.

In Lebanon, the population is separated into eighteen officially recognized religious sects, the most predominant being Sunni Muslims, Shite Muslims, and Maronite Christians. Within the remaining minority groups there are three other Islamic sects the Alawite, the Duze and the Ismaili-eleven other Christian sects including the Greek Orthodox and the Greek Catholics, and finally the Jewish community (US Department of State, n.d.). The last official census which gives the proportions of each religious sect dates back to 1932 , under the French rule. There have however been significant demographic changes in the past century, such as a big influx of Palestinian Sunni Muslims (Erni 2013) and the exodus of Lebanese Christians, which have thus increased the proportion of Muslims and decreased the proportion of Christians (CIA 2018).

On the other hand, the division of groups in Iraq is generally described as being sixty percent Shia, twenty percent Sunni, and twenty percent Kurds (Patel 2019, 152). Because the Kurds refer to an ethnic group whereas the Sunnis and Shiites are religious groups, this division can be misleading as they appear to be three mutually exclusive identity groups. In reality, the Shia and Sunni groups referred to previously only include the Shia and Sunni Iraqi Arabs. While the Kurds are also majoritarily Muslim (predominantly Sunni and some Shiites), they ultimately identify more strongly to their ethnic group rather than their religious group. Nonetheless, an often forgotten three percent of the population is composed of different minority groups: Turkmen/Turcoman, Yazidis, Shabaks, Kaka'i, Bedouins, Roma, Chaldeans, Assyrians, Circassians, Sabaean-Mandaean, and Persians. These, contrary to Lebanese minority groups, are often forgotten and as such not officially recognized on

Another significant difference in the ethnic and religious composition of Lebanon and of Iraq is their geographic organization. This difference is significant as it could lead to differences in the management of these groups. Indeed, whether or not the groups are geographically separated represents an important factor behind the Kurds' allegiance to their ethnic or religious groups. In Lebanon, the religious groups agglomerate roughly in separate regions. For example, Maronites are thest, Shias are mainly in the North Eastern and Southern areas, and Sunnites are mainly concentrated close to the Syrian border in the North and in the East (CIA 2018). However, these religious groups cohabitate as they are still very mixed and geographically dispersed across Lebanon. In contrast, there is a much more clear cut division in Iraq. The three predominant sub-communities are highly divided 
geographically: Shias in the South, Sunnis in the North West, and Kurds in the Northern part of the country. The minorities are more broadly scattered across the different territories (Holden 2015).

\section{Historical Background}

While integration of ethnic and religious groups in politics has been present in Lebanon since the Ottoman rule, Iraqi politics were essentially secular until the 2003 US coup. Under Ottoman rule, the Lebanese identified most strongly with their religious identities, creating tensions between them. This led to an early version of confessionalism in 1860 , where "a council was elected based on sectarian allocations in the population in order to end violence between the Druze and Maronites" (Kisthardt 2013, 10). When in 1920 the French took over, they reinforced the religious divisions, as the internal tensions strengthened their control as colonizers. On the other hand, when Iraq freed itself from British colonial rule in 1932, it was built on the concept of secularism, with a high degree of separation between religion and politics (Baram, Rohde and Zeidel 2016). Under the reign of president Saddam Hussein (r. 19792003), religious identities began increasing importance with for instance a growing Shia opposition to his Sunni government. However this was still all occurring under the umbrella of Ba'athist ideology - a movement of Arab nationalism founded on secularism (Devlin 1991).

Although in different forms, ethnoreligious tensions were present in both countries Throughout the procedure of gaining independence from France, Lebanese Christians feared being overwhelmed by the Muslim communities, while the Muslims feared Western hegemony. They were able to come to a temporary agreement through the the National Pact in 1943, which laid the foundation for the consociational system: "in return for the Christian promise not to seek foreign, i.e., French, protection and to accept Lebanon's 'Arab face,' the Muslim side agreed to recognize the independence anese state in its 1920 boundaries and to renounce aspirations for union with Syria" (US Department of State, n.d.). The National Pact officialised the confessional distribution of power in the government based on the 1932 census (US Department of State, n.d.). Nevertheless, as mentioned earlier, despite a lot of quick demographic changes, especially with the early 1948 Palestinian refugee influx, no new census was conducted which meant there were no readjustments to representation 2007). Therefore, the disproportionate representation evidently led to social discontent from the underrepresented groups. This exploded into a Civil War that opposed different militias of the different sects. The war culminated in the Taif Agreement of 1990 which rebalanced power by switching the five to six parliamentary ratio in favor of Christians to a one to one ratio (Malley 2018, 121-159). In Iraq, tensions had been rising throughout Hussein's rule within the Shia majority, which resented being ruled by the Sunni minority. Tensions also increased between the government and the Kurds. Indeed, the 1991 Gulf War had also been the stage for Iraqi political violence against the Kurds, in what is known as the al-Anfal Campaign. The justification for its launch was that the Kurds had been 'disloyal' (CJPME 2008). This led to the Kurds establishing their own regional government in 1992. Ultimately, these underlying tensions boiled up and fully emerged after the 2003 toppling of the Saddam regime left Iraq without any cohesive alternative government. These ethnoreligious internal divisions led to intense violence between the groups, verging on a complete civil war by 2006 . Thus, during this period, Iraqis' primary identity was their religious or ethnic group. Fearing for their personal interests, when Iraqis cast their votes in the 2005 elections it was along identity, sectarian lines not because of an actual support for the candidates' platforms (Marr 2010, 15-41).

Political Systems in Place and Their Confessionalism

Although it is only formally formulated in Lebanon, these dynamics have caused both countries to have political systems that deal with their country's pluralism through a sort of confessionalism In Lebanon, following the decisions of the Taif Agreement, the different positions in government are appointed in terms of religious affiliation. Every parliamentary seat is accorded to each of the eighteen officially recognized religious groups in an attempted proportional divide. Moreover, the President position is reserved for a Maronite Christian, while the Prime Minister a Sunni Muslim and the speaker of the parliament a Shiite (Matamoros 2020). While this system is based on the foundation of confessionalismrepresenting the different groups proportionately in government-it is important to note that the currently established one to one ratio of Muslims to Christians in parliament is not an accur proportional representation as it is not based on an up to date census of the Lebanese population.

Iraq is "an Islamic, democratic federal republic, consisting of 18 governorates (muhafazat)" (Fanack 2020). The Kurdistan Autonomous Region is one of them. This federal system alternative is possible in Iraq but not in Lebanon due to the geographic disposition of the groups. However, there are also some ethnosectarian confessional patterns, which are known as the muhasasa in Iraq. These implicitly ensure that power is shared proportionally between the three main demographics (Abdulrazaq 2019). Without any formal or legal documentation, it reserves the presidency for an Iraqi Kurd, the premiership for a Shia Muslim, and the speaker for the minorities who are forced to align with bigger political parties. Although Lebanon and Iraq have different political systems, both countries have ultimately incorporated some form of confessionalism in their strategy to cope with their ethnic and religious pluralism. The question that remains is whether this method is successful at managing the tension-inducing diversities.

\section{Current Instability Due to the Inevitable Shadow of Confessionalism: Sectarianism}

Since 2019, both Lebanon and Iraq have been facing massive public protests requesting the complete transformation of each country's respective political system. In fact, according to surveys conducted in both countries by the Arab Barometer, only around two percent of the population in both countries trust the government in place (Arab Barometer, n.d.). This suggests that confessionalism is unsuccessful. However, confessionalism is not directly the target of these protests. Rather, what both Iraqis and Lebanese people are protesting is corruption, political incompetence, and economic hardship (Serhan 2019). Lebanese people are also particularly dismayed by the lack of public services available to them. Moreover, Iraqis chant "out, out Iran" due to their disapproval of Iran's strong influence on the Shia governmental positions in Iraq (BBC 2019). Although neither population criticizes confessionalism directly, the problems being highlighted in both countries seem to be direct or indirect causes of sectarianism (Ataha 2019).

Sectarianism and its Corruption as an Inevitable Consequence of Confessionalism

Sectarianism is defined as a discriminatory political structure in which each group, and particularly its elite, seeks their own privileges at the expense of others. Both Iraq and Lebanon tried protecting their systems from this phenomenon. In fact, the Taif Accord proposed to diminish sectarianism by "suggesting that posts in the civil service be merit-based, instituting educational changes to promote national unity and removing sectarian labels from identity cards"(CJPME 2007). A2016 Iraqi law also attempted to curb sectarianism by allowing for the banning of any political group which "supports racism, terrorism, sectarianism and sectarian cleansing" (Freedom House 2020).

Yet in both cases sectarianism appears to be a 
natural and inevitable corollary to confessionalism. Indeed, "the allocation of political offices by sect, which makes access to power and resources contingent on communal affiliation, boosts the salience of religion in political and social life" (Cammett 2019). This separation of power by ethnic or religious groups makes members of a country feel most strongly attached to their group rather than to their nation; every subgroup feels like it will only be properly represented by the representative of its faction in politics. Therefore, this leads to a mistrust in other parties and fosters a strong, exclusive and blind support for one party. Ultimately, the confessional system creates an incentive for community leaders to consolidate the 'vertical' integration of their communities rather than the development of horizontal, cross-cutting interests (CJPME 2007). In turn, there is a reduction of government transparency as the blind loyalty of party followers forgoes accountability. This has "produced in each country 'a political class that "pas operated its own webs of patronage" (Serhan 2019). It also enabled "personal and party financial expenses that are huge and disproportionate to the overall budget"(Al-Azawi, n.d.). Indeed, both the Iraqi and Lebanese political elites are encouraged by this system to participate in corruption.

Ultimately, the confessional system in both countries provides each sect's representative with too much unconditional support, allowing them to seek personal gain through these government functions in which they should instead be looking for the welfare of the entire nation (Thelwell 2020). Confessionalism is thus counterproductive as instead of providing each group with a voice to ensure that their needs are not forgotten, it provides an avenue for sectarian leaders to undermine other factions. Rather than appeasing the tensions that arise from the inherent diversity of both countries, confessionalism has led to each sect fearing for itself and thus widening the divide. Thus for the rest of this paper, if something is said to be caused by sectarianism, it will be implied that this itself is caused by the confessional system.

International Interferences as a

Consequence of Sectarianism

Another issue the Lebanese and Iraqis have raised is the constant presence of international actors in their national politics, which threatens their sovereignty. The cause of this interference can easily be linked back to sectarian politics for two main reasons.

For one, the stronger allegiance to a sect rather than to a nation has made each ethnic or religious political group reach out to similar groups in other nations for support. Thus, fearing that it will be overwhelmed by the other sects of the country, each party has looked for support in governments of similar ideology that have the means to back them and protect their positions in the system. An example of this is how in both Iraq and Lebanon, the major Shiite groups have turned to Iran, a strong and established Shiite regime, for financial and military support. Indeed, the Shiite Fateh Alliance, which holds forty-eight of the 329 seats in the Iraqi Council of Representatives, is an Iranian-backed group made up of leaders of militias that fought ISIS (Hanna and Nada 2020). Similarly, the leading Shiite political party in Lebanon-Hezbollahreceives its support mainly from Iran, which provides over $\$ 700$ million per year in weaponry and more (Council on Foreign Relations, n.d.). This is a huge problem for the Lebanese and Iraqis, as evidently these Iranian-backed groups will have an incentive to push the Iranian agenda in both countries, at the expense of these nations' needs.

Secondly, even if parties do not directly seek support from international actors, sectarian politics have provided the instability allowing regional actors to intervene and benefit from the insecurity. In fact, the clash between the vertical interests and integration of each sect and the horizontal economic and social interests of the nation as a whole has instilled an instability which regional actors have exploited and actually increased (United States Institute of Peace 2013). Indeed, it is evident that for nearby countries, sectarianism is beneficial as it weakens the national identity and thus the national strength of a potentially threatening neighbor. Thus, international actors have backed sectarian groups to ensure that these groups push their agenda and that the country remains divided (Abdulrazaq 2019).

Domestic Grievances as a Consequence of Sectarianism

Domestic grievances linked to a lack of public services, a major factor in the protests, are also in part linked to sectarian politics. The lack of national unity and the weakness of the state government due to each party's individual strength prohibits the creation of strong nationa welfare systems. Rather, this system allows for the formation of welfare providers along the religious and ethnic lines which thus can lead to "sectarian discrimination when providing services" (AlAzawi, n.d.). In fact, the sectarian system has allowed Lebanon's politicians to choose "personal enrichment over public welfare, leading to dismal internet connectivity, insufficient health care, contaminated water and unreliable power sources" (Thelwell 2020). An example of this is the 2015 garbage crisis in Lebanon. In mid-July 2015, the Lebanese Ministry of Environment closed a landfill in the south of Beirut without first selecting an alternative site, leading to an extreme accumulation of trash on the streets of the country. As for many public services in Lebanon, they are provided by companies which are each affiliated with a sect and thus a political figure or party. The issue lasted for such a long time because the country's politicians be awarded the luct be awarded the lucrative garbage collection contracts" (Carnegie Middle East Center, n.d.) The Druze leader Walid Jumblatt went so far as to sarcastically tweet a "suggestion to establish an independent garbage dump for each religious sect in Lebanon" (Carnegie Middle East Center, n.d.). A similar pattern exists for water and electricity distributions which are to this day consequential issues in Lebanon. This demonstrates that even issues which on the façade do not seem linked to the management of the ethnic and religious pluralism, are in reality linked to it. Therefore, it is evident that a lot of the issues Iraqi and Lebanese protesters are pointing out are either directly or implicitly linked to sectarianism and therefore to the way the government has managed ethnic and religious pluralism. The question now is whether religious pluralism. The question now is whether
these protests can lead to any changes in the these protests can
foreseeable future?

\section{Sectarianism as a Positive Feedback}

\section{Trap Prohibiting Change in the}

\section{Foreseeable Future}

For the protests to lead to substantial change there would have to be a radical transformation in the political system to remove sectarianism, the root of many of the problems. This would therefore entail a complete rethinking of how the various ethnic and religious identities are integrated in politics. Thus, political elites and the population would have to collaborate to make this possible. Evidently, such a change would be detrimental to the current political elites who are too invested and who personally benefit from the status quo. It would also be quite difficult to convince the people to completely eliminate the confessional affiliations in government as its initial existence has caused an overtake of subgroup identities over national identity.

\section{Resistance of Political Elites}

Political elites in both Iraq and Lebanon have already resisted and will continue to resist any substantial change. Indeed, for those in power in both Iraq and Lebanon, the system in place is beneficial. A "closed feedback mechanism" has been created, which recycles the same political figures over and over again (Al-Shadeedi and Van Veen 2020). The sectarian affiliations have also made it extremely easy for the political elites to come and stay in power: regardless of their competence and without needing to develop complex campaigns or political platforms, they have been able to hold power solely because people vote blindly for the representative of their group (Al-Shadeedi and Van Veen 2020).

Moreover, the corrupt system makes it easier for the political elites to resist change by lowering the expectations of their accountability. 
In fact, the corruption that comes hand in hand with the sectarian system allows political elites to get away with many schemes, even when there are supposedly institutions in place to avoid such issues. For example, "even though Iraq has an Integrity Commission whose independence is assured by the Constitution, it has thus far failed to meaningfully prosecute high-level politicians or officials with ties to one of Iraq's larger political parties for corruption" (Al-Shadeedi and Van Veen $2020,14)$. In both countries, the protests have led to the removal of some of the political elites, but not to any substantial change; the new elected candidates fit right back into the system. The fundamental issue is not necessarily the elites, but rather, the system which gives them too much power

\section{The Identity Dilemma}

Recent protests have revealed that Iraqis and Lebanese alike are urging for national unity to fight the dysfunctional political system based on sectarianism. However, in practice, it will be very difficult to actually convince people to vote out of sectarian lines. Indeed, for one, as discussed earlier, the simple existence of these confessiona systems all these years have caused a sort of identity dilemma. The confessional emphasis in both states has encouraged greater allegiance to the sectarian party than to the state, causing an identity dilemma. Furthermore, "confessional emphases create dependencies within one's ethnic group, e.g. religious institutions exercise direct control over many facets of daily life" (CJPME 2007). Because daily life's primary needs are met by the sectarian parties, renouncing them could first mean renouncing access to basic necessities. Thus, even individuals who protest against the governmen would be afraid to vote out of sectarian lines, in fear of losing their group's voice and rights. National identity and unity may be growing through these protests, which is a positive and hopeful sign, but actual change will first require the sectarian leaders to work together in order to ensure that basic needs will be provided regardless. However, as discussed earlier, it does not seem as though cooperation from the political elites will come soon. Moreover, the sectarian system limits the power of neutral candidates such that it would thus be useless to vote for them. Therefore, for the time being, it is unrealistic to expect that a majority of Iraqis or Lebanese will renounce their sectarian party. There is some hope that the recent advancements such as the economic crisis linked in part to the COVID-19 pandemic in both countries and the continuing protests triger a start of change. However, wever, significant change would require a complete shift of system which is extremely difficult to
acquire, especially in precarious times like today.

\section{Conclusion}

Deep ethnic and religious divisions within a country are evidently difficult to manage and to integrate fairly into a political system, especially when ethno-sectarian tensions are deeply rooted. However, it is also evident that in order to instate a stable democratic political system, every citizen needs to feel heard, represented, and respected. Therefore, it is crucial to find a system to successfully manage these ethnic and religious pluralisms.

Iraq and Lebanon are two examples of Middle Eastern states with a rich ethnic and religious diversity that needs to be weaved into the political system. Although these two countries differ in many fundamental ways due to their differing ethnic and religious compositions and histories, they share similar outcomes. In fact, both countries have integrated their most prominent sub-identity groups into their political structures by allocating proportional power to each group. Thus, both systems employ a form of confessionalism.

The idea behind confessionalism is to give each ethnic and religious group a voice in government in order to ensure that their needs are covered. The goal is thus to ensure that the nation as a whole runs well and everyone is satisfiedsuggesting that electors will vote for the most competent candidates who will best support nation as a whole. However, it is ultimately an unsuccessful system to manage ethnic and religious pluralism because it leads to sectarianism which itself leads to instability due to the corruption, domestic grievances, and undesirable international interventions that come with it (United States Institute of Peace 2013). The particular danger of this system is that it is very difficult to escape. Indeed, not only is confessionalism self-reinforcing, this system also causes other seemingly bigger issues which detract focus from its foundational issues, although people may want to escape it.

If the Lebanese and Iraqis want political change, they will have to request radical reform which aims not only at uprooting sectarianism but confessionalism as a whole. Thus, a possible avenue would be secularism: complete separation of religion and politics. This would allow for political elites to be chosen for their political platforms and their merit rather than their ethnic or religious affiliation which people will identify with. Unfortunately, this is not realistic for the short-term. However, it may be possible in the the principal actors of the current protests, shift their sense of identity to a national one rather than to a sectarian one.

\section{References}

Abdulrazaq, Tallha. 2019. "Confessional politics ensured Iran's colonisation of Iraq." The Arab Weekly. December 4, 2019. Accessed November 25, 2020. https://thearabweekly. com/confessional-politics-ensured-iranscolonisation-iraq

Ali, Zahra and Khalaf, Safaa. 2019. "In Iraq, demonstrators demand change - and the government fights back." Washington Post. October 9, 2019. Accessed November 25 , 2020. https://www washingtonpost.com/ politics/2019/10/10/iraq-protestors-demandchange-government-is-fighting-back/.

Al-Shadeedi, Hamzeh and Van Veen, Erwin. 2020. "The trouble with elite inclusiveness on sectarian grounds: Iraq's adolescent democracy." Clingendael Institute. Accessed November 25, 2020. https://www.clingendael. org/pub/2020/iraqs-adolescent-democracy/2the-trouble-with-elite-inclusiveness-onsectarian-grounds/.
Al-Azawi, Muhanned. n.d. "Iraq's Nexus of Sectarianism and Corruption. Iraq's Nexus of Sectarianism and Corruption." The

Washington Institute for Near East Policy. Accessed November 25, 2020.https://www. washingtoninstitute.org/policy-analysis/iraqsnexus-sectarianism-and-corruption.

Angrist, Michelle Penner. 2019. "Iraq;" In Politics \& Society in the Contemporary Middle East. CO: Lynne Rienner Publishers, Inc (Ed.) Boulder.

Arab Barometer. n.d. "Data Analysis Tool." Arab Barometer. Accessed November 25, 2020. https://www.arabbarometer.org/survey-data/ data-analysis-tool/.

Banchoff, Thomas. 2018. Religious pluralism, globalization, and world politics. Oxford: Oxford Univ. Press.

Baram, Amatzia, Rohde, Achim, and Zeidel, Ronen. (Eds.). 2016. Iraq between occupations: Perspectives from 1920 to the present. Palgrave Macmillan. U.S.

BBC. 2019. "The Iraq protests explained in 100 and 500 words." BBC. December 2, 2019 Accessed November 25, 2020. https://www. bbc.com/news/world-middle-east-50595212.

Cammett, Melani. 2019. "Lebanon, the Sectarian Identity Test Lab." Accessed November 25, 2020. https://tcf.org/content/report/lebanonsectarian-identity-test-lab/?session $=1$.

Canadians for Justice and Peace in the Middle East (CJPME). 2007. "Understanding Lebanese Confessionalism." Accessed November 25, 2020. https://www.cjpme.org/fs_026.

Canadians for Justice and Peace in the Middle East (CJPME). 2008. "Challenges to a National Identity in Iraq." Accessed November 25, 2020. https://www.cjpme.org/fs_046

CIA. 2018. "The World Factbook: Lebanon."Accessed November 25, 2020. https://www.cia.gov/library/publications/the world-factbook/geos/le.html

Fanack. 2020. "Governance \& Politics of Iraq." Accessed November 25, 2020. https://fanack. $\mathrm{com} / \mathrm{iraq} /$ governance-and-politics-of-iraq/.

Freedom House. 2020. "Iraq: Freedom in the World 2020." Freedom House. Accessed 
November 25, 2020. https://freedomhouse.org country/iraq/freedom-world/2020.

Henley, Alexander. 2016. "Religious Authority and Sectarianism in Lebanon." Carnegie Endowment. Accessed November 26, 2020. https://carnegieendowment.org/2016/12/16/ religious-authority-and-sectarianism-inlebanon-pub-66487.

Holden, Stacy. 2015. "The Secular Roots of a Religious Divide in Contemporary Iraq". Origins. Accessed November 25, 2020. https:// origins.osu.edu/article/secular-roots-religiousdivide-contemporary-iraq.

Kisthardt, Laura. 2013. "Confessionalism in Lebanon: Reflection and an analysis of issues." Accessed November 25, 2020. https://collected.jcu.edu/cgi/viewcontent. cgi?article $=1014 \&$ context $=$ honorspapers

Marr, Phebe. 2010. One Iraq or Many: What Has Happened to Iraqi Identity. In Iraq between occupations: Perspectives from 1920 to the present (pp. 15-41). New York: Palgrave Macmillan.

Matamoros, Cristina. 2020. "How does Lebanon's government work?." Euronews. April 1, 2020 Accessed November 25, 2020. https://www. euronews.com/2019/10/21/how-does-lebanons-government-work-euronews-answers.

Muasher, Marwan. 2019. "Is This the Arab Spring 2.0?." Carnegie Endowment

Accessed November 25, 2020.https://

carnegieendowment.org/2019/10/30/is-thisarab-spring-2.0-pub-80220.

Murray, Christina. 2018. "Constitutions:

Frameworks for Pluralism?." Accessed

November 25, 2020. https://www.pluralism.ca/ wp-content/uploads/2019/01/ChristinaMurray Constitutions_EN.pdf

National Democratic Institute. 2019. "Focus Group Report: Iraqi Citizens Continue to Demand More Responsive Governance." National Democratic Institute. Accessed November 27, 2020. https://www.ndi.org/ publications/focus-group-report-iraqi-citizenscontinue-demand-more-responsive-governance.
Robinson, Kali. 2020. "What Is Hezbollah?." Council on Foreign Relations. September 1 , 2020. Accessed November 25, 2020. https// 2020. Accessed Novenber 25, 2020. https://

Serhan, Yasmeen. 2019. "The Nationalist Movements Against Sectarian Politics." The Atlantic. October 30, 2019. Accessed November 25, 2020. https://www.theatlantic. com/international/archive/2019/10/ new-nationalist-movements-iraq-andlebanon/601021/.

Stansfield, Gareth. 2016. Iraq: People, history, politics. Cambridge, UK: Polity Press.

Thelwell, Kim. 2020. "Corruption in Lebanon and Its Consequences." The Borgen Project. Accessed November 25, 2020. https:// borgenproject.org/corruption-in-lebanon/

United States Department of State. n.d. "International Religious Freedom Report for 2015". United States Department of State. Accessed November 25, 2020. https://2009-2017.state.gov/j/drl/rls/irf/ religiousfreedom/index.htm\#wrapper.

United States Institute of Peace. 2013.

"Lebanon's Confessionalism: Problems and Prospects." United States Institute of Peace. Accessed November 25, 2020. https://www. usip.org/publications/2006/03/lebanonsconfessionalism-problems-and-prospects. 